\title{
Mineral deficiencies influence on tomato leaves: pigments, hydrogen peroxide and total phenolic compounds contents
}

\author{
Khalid Y. Alsharafa \\ Department of Biological Science, Faculty of Science, Mutah University, Mutah- Karak 61710, P.O. Box(7), \\ Jordan
}

*Corresponding author: k.sharafa@mutah.edu.jo

\begin{abstract}
The detection of hydrogen peroxide, chlorophyll pigments, anthocynin, carotenoids, total phenolic compounds and lipid peroxidation levels as potential stress signaling molecules in tomato (Lycopersicon esculentum Mill.) leaves in response to specific mineral deficiency were studied. The stress signaling molecules were measured in the plant leaves at different growth time points cultured in specific mineral deficient nutrient solutions. The results showed that hydrogen peroxide was significantly increased after 48 and $72 \mathrm{~h}$ of growth in $\mathrm{NO}_{3}{ }^{-}$and $\mathrm{S}$ deficient nutrient solutions. While the significant accumulation of $\mathrm{H}_{2} \mathrm{O}_{2}$ in the plant leaves was observed after $72 \mathrm{~h}$ and $96 \mathrm{~h}$ of growth in $\mathrm{K}^{+}$deficient nutrient solution. In the case of $\mathrm{Mg}^{2+}$ and $\mathrm{Fe}^{2+}$ deficiency the significant accumulation was observed after $72 \mathrm{~h}$ cultivation. The only significant reduction in chlorophyll $a$ content was detected after $96 \mathrm{~h}$ cultivation under $\mathrm{Mg}^{2+}$ specific deficiency with no significant changes due to $\mathrm{NO}_{3}{ }^{-}, \mathrm{SO}_{4}{ }^{2-}, \mathrm{Fe}^{2+}, \mathrm{K}^{+}, \mathrm{Ca}^{2+}$ and $\mathrm{PO}_{4}{ }^{2^{-}}$deficiencies. Meanwhile, chlorophyll $b$ contents were significantly reduced in the plant leaves grown for $48 \mathrm{~h}$ under $\mathrm{Mg}^{2+}$ and $\mathrm{Ca}^{2+}$ specific mineral deficiency. Longer cultivation in $\mathrm{Mg}^{2+}$ dificient hydroponic culture for $96 \mathrm{~h}$ resulted in $215 \%$ increment in chlorophyll $b$ content. No significant changes in chlorophy $b$ contents were detected in hydroponic cultures dificient in $\mathrm{NO}_{3}{ }^{-}, \mathrm{SO}_{4}{ }^{-}, \mathrm{Fe}^{2+}$, and $\mathrm{PO}_{4}{ }^{2-}$. Impose of minerals deficiencies on anthocyanins and carotenoids contents were showed parallel changes. Both increased significantly in response to $\mathrm{PO}_{4}{ }^{2-}$ and $\mathrm{NO}_{3}{ }^{-}$specific deficiencies after $48 \mathrm{~h}$ and in the case of $\mathrm{Mg}^{2+}$ deficiency after $72 \mathrm{~h}$. Meanwhile, $\mathrm{SO}_{4}{ }^{2-}$ deficiency caused the significant increase of both after $72 \mathrm{~h}$ and $96 \mathrm{~h}$. Regarding TPC the results clarified that $\mathrm{Mg}^{2+}, \mathrm{Ca}^{2+}$ and $\mathrm{K}^{+}$specific deficiencies caused significant reductions that appeared after $48 \mathrm{~h}$. In contrast, $\mathrm{S}$ deficiency caused significant increase in TPC values after $72 \mathrm{~h}$. On the other hand, the estimated levels of MDA showed significant increment under $\mathrm{Ca}^{2+}$ and $\mathrm{K}^{+}$and $\mathrm{PO}_{4}{ }^{2-}$ specific deficiencies at all time points while in the case of $\mathrm{Mg}^{2+}$ and Fe deficiencies the increment was first reported after $48 \mathrm{~h}$ and with the later one (Fe) the increment continues up to $96 \mathrm{~h}$. These results indicate that some of presented metabolites could be used as stress markers. These results support the possible role of anthocyanins, carotenoids, hydrogen peroxide, total phenolic compounds contents and MDA as early signaling metabolites in tomato plants under specific mineral deficiency.
\end{abstract}

Keywords: Abiotic stresses; Acclimation; Antioxidants; Mineral deficiency; Signals.

Abbreviations: Chl_chlorophyll; FW_fresh weight; GAE_gallic acid equivalents; MDA_malondialdehyde; ROS_Reactive oxygen species; TCA_trichloroacetic acid; TPC_Total phenolic compounds.

\section{Introduction}

At global scale, crop plants affected by the continuous deterioration of soil properties since it influence the form, amount, retention and movement of soil nutrients. Therefore, poor cultivation soil causes decrease in global food production and in particular in the developing countries. At the physiological and molecular levels, deficiencies in essential minerals like other abiotic stresses experienced by plants in many different ways. Eventually, adaptation or acclimation occurs over different time scale affected by the dose of exposure, plant development stage and combinations of different stresses which are a critical determinant for plant productivity (Wang et al., 2002; Wang \& Wu, 2010). When essential mineral nutrients are scarce, several molecular and physiological events such as photosynthesis rate and appearance of chlorosis are responsible for sensing and signaling mineral resources limitation. Therefore, their ultimate effects on plant development and biomass allocation need for further investigation. In particular, the information's about upstream molecular targets which are limited until recently (Hermans et al., 2006; Kehr, 2013; Verbruggen \& Hermans, 2013). Phenolic compounds are secondary metabolites that found in leaves, flowers and fruits. Metabolically, their chemical precursor is the amino acid phenylalanine. Phenolic compounds play an important role in plant metabolism as plant hormone controllers and protectant of plants against stresses. They play a major role in the process of plant interaction with their environment. Hence, they tend to accumulate in dermal tissues where they introduce their ability as a potential protecting agent against different abiotic and biotic stresses. In addition, they act as attractants in fruit dispersal, as structural materials and showed signaling properties (Garcia-Salas et al., 2010; Sakihama et al., 2002; Tsao \& McCallum, 2009). In accordance, anthocyanins are group of phenolic compounds where their production and accumulation might be influenced by several abiotic factors (Chon et al., 2012; Do \& Cormier 1991; Kobayashi et al., 1993; Mori \& Sakurai 1994; 
Nakajima et al., 1989; Wellmann et al., 1976; Zhang et al., 1997; Zhong et al., 1991).

In relation, hydrogen peroxide accumulation in response to stress conditions reported to play a dual role in plants according to the accumulation level in plant cells. At low accumulation levels it can act as a signal molecule triggering acclimation response to different biotic and abiotic stresses. Where at high accumulation levels it provokes programmed cell death (Gao et al., 2010; Quan et al., 2008; OrozcoCárdenas et al., 2001; Prasad et al., 1994).

Recently, metabolome analyses have involved addressing the internal environment adjustment of the plant in response to minerals deficiencies. In this study, the analyzed metabolome were limited to the pigments (chlorophyll, anthocyanins and carotenoids), hydrogen peroxide, total phenolic compounds contents and lipid peroxidation level in tomato (Lycopersicon esculentum Mill.) leaves at different growth time points on specific mineral $\left(\mathrm{Mg}^{2+}, \mathrm{Ca}^{2+}, \mathrm{Fe}, \mathrm{K}^{+}\right.$, $\mathrm{P}, \mathrm{N}, \mathrm{S})$ deficiencies.

\section{Results}

\section{Hydrogen peroxide accumulation}

It have been reported that reactive oxygen species (ROS) tend to accumulate in response to different stress conditions where they act as signaling molecules (Sharma et al., 2012; Trachootham et al., 2008; Tuteja \& Sopory, 2008). In agreement, the results in Fig. 1 showed that early $\mathrm{H}_{2} \mathrm{O}_{2}$ significant accumulation were detected in tomato leaves grown in hydroponic cultures deficient in $\mathrm{NO}_{3}^{-}$and $\mathrm{SO}_{4}{ }^{-}$ after $48 \mathrm{~h}$ of incubation reaching 1.6 and 1.4 folds, respectively. The results also revealed that these significant increments were continue and reached high levels of 4.1 and 3.7 folds after $72 \mathrm{hs}$ which later on (after $96 \mathrm{hs}$ cultivation) sharply decreased, as acclimation response, to nonsignificant levels compared to the control treatment. In the case of $\mathrm{Mg}^{2+}$ and $\mathrm{Fe}^{2+}$ deficiencies the earliest significant accumulation of $\mathrm{H}_{2} \mathrm{O}_{2}$ were appeared at $72 \mathrm{~h}$ and reached 2.2 and 1.5 folds, respectively. Similar to $\mathrm{NO}_{3}{ }^{-}$and $\mathrm{SO}_{4}{ }^{-}$treatments, longer cultivation (96h) of tomato in hydroponic cultures deficient in $\mathrm{Mg}^{2+}$ and $\mathrm{Fe}^{2+}$ leads to reduction of $\mathrm{H}_{2} \mathrm{O}_{2}$ amounts to nonsignificant levels as compared to the complete culture. In the case of $\mathrm{K}^{+}$deficiency, the significant reduction in $\mathrm{H}_{2} \mathrm{O}_{2}$ production was measured at 72 and $96 \mathrm{~h}(0.9$ and 0.75 , respectively).

\section{Chlorophyll $a$ and $b$ contents}

In this experiment, chlorophyll content as indirect tool for estimation of bioproductivity and to understand the photosynthetic regime of plant under specific mineral deficiencies were studied. The results (Fig. 2A, B and C) showed that the only significant change (49\% reduction) in chlorophyll a content was detected in Lycopersicon esculentum Mill. leaves after $96 \mathrm{~h}$ cultivation under $\mathrm{Mg}^{2+}$ specific deficiency. On the other hand, no significant changes in chlorophy $a$ contents were detected in tomato leaves grown in hydroponic cultures dificient in $\mathrm{NO}_{3}^{-}, \mathrm{SO}_{4}{ }^{-}, \mathrm{Fe}^{2+}, \mathrm{K}^{+}$and $\mathrm{PO}_{4} 2^{-2}$ compared to the tomato leaves of the plant grown in complete culture. However, the analysis of chlorophyll $b$ content in the plant leaves grown under $\mathrm{Mg}^{2+}$ and $\mathrm{Ca}^{2+}$ specific mineral deficiency revealed that a significant reduction of 56 and $47 \%$ in chlorophyll $b$ content were measured in tomato leaves after $48 \mathrm{~h}$ incubation. Meanwhile, longer cultivation (72 and 96h) of tomato in $\mathrm{Mg}^{2+}$ dificient hydroponic culture caused contineous increament in chlorophyll $b$ content reached to signifcant levels of $215 \%$ after $96 \mathrm{~h}$ cultivation in comparsion to that grown in complete nutreint solution. On the other hand, no significant changes in chlorophy $b$ contents were detected in tomato leaves grown in hydroponic cultures dificient in $\mathrm{NO}_{3}{ }^{-}, \mathrm{SO}_{4}{ }^{2-}, \mathrm{Fe}^{2+}$ and $\mathrm{PO}_{4}{ }^{2-}$ compared to the tomato leaves of the plant grown in complete culture.

\section{Anthocyanins contents}

Figure 3. showed that the effect of specific mineral deficiencies on anthocyanins content appeared as time dependent and mineral specific response. The results showed that the significant increment of 2.5 and 2.9 folds in anthocyanins content recorded after $48 \mathrm{~h}$ cultivation apeared in $\mathrm{PO}_{4}^{2-}$ and $\mathrm{NO}_{3}^{-}$specific depleted nutreint solutions, respectivelly. While after $72 \mathrm{~h}$ the significant increment of 8.7 and 2.1 folds in anthocyanins content recorded in $\mathrm{Mg}^{2+}$ and $\mathrm{SO}_{4}{ }^{2-}$ specific depleted nutreint solutions, respectivelly. However, eventhough longer cultivation of tomato in $\mathrm{SO}_{4}{ }^{2-}$ specific depleted nutreint solution up to $96 \mathrm{~h}$ resultede in reduction of anthocyanins content as compared to anthocyanins content recorded at $72 \mathrm{~h}$ the magnitude of anthocyanins content still significantly higher (1.3 folds) than the control experiment. On the other hand, no significant changes in anthocyanins content were detected in tomato leaves grown in hydroponic cultures dificient in $\mathrm{Ca}^{2+}, \mathrm{K}^{+}$ and $\mathrm{Fe}^{2+}$ at all cultivation times studied compared to the tomato leaves of the plant grown in complete culture.

\section{Carotenoids contents}

In agreements with the anthocyanins content results (Fig 3.) the results of carotenoids content (Fig 4.) also showed no significant changes recorded in tomato leaves when the plant grown in hydroponic cultures dificient in $\mathrm{Ca}^{2+}, \mathrm{K}^{+}$and $\mathrm{Fe}^{2+}$ at all cultivation times studied compared to the tomato leaves of the plant grown in complete culture. Meanwhile, carotenoids contents were significantly increased and reached 2.1, 2.4 and 1.9 folds in the plant leaves when cultivated for $48 \mathrm{~h}$ in $\mathrm{PO}_{4}{ }^{2^{-}}$, $\mathrm{NO}_{3}{ }^{-}$and $\mathrm{SO}_{4}{ }^{2-}$ specific depleted nutreint solutions, repsectively. In the case of $\mathrm{Mg}^{2+}$ and $\mathrm{SO}_{4}{ }^{2-}$ dificient hydroponic cultures the significant increment ( 7.7 and 1.8 folds, respectivelly) in carotenoids content were recorded after $72 \mathrm{~h}$ cultivation. After $96 \mathrm{~h}$ cultivation, only tomato leaves of tomato plants grown in $\mathrm{SO}_{4}{ }^{2-}$ specific depleted nutreint solution recorded significantly higher carotenoids contents compared to the leaves of the control experiment.

\section{Total phenolic contents}

The results shown in Fig 5. showed that the earliest response (at $48 \mathrm{~h}$ ) in total phenolic compounds content as significant decrease $(0.6,0.72$ and 0.63 folds) were appeared in the tomato leaves of the plants that grown on $\mathrm{Mg}^{2+}, \mathrm{Ca}^{2+}$ and $\mathrm{K}^{+}$ specific depleted nutreint solutions, respectivelly. Eventhough the values of the total phenolic compounds content in the tomato leaves taken from the plants grown in $\mathrm{Fe}^{2+}, \mathrm{PO}_{4}{ }^{2^{-}}, \mathrm{NO}_{3}{ }^{-}$and $\mathrm{SO}_{4}{ }^{-2}$ dificient cultures were less than that reported with the control experiment the differences were nonsignificant. In contrast, at $72 \mathrm{~h}$ cultivation time, the analysis of total phenolic compounds content in tomato leaves of the $\mathrm{Mg}^{2+}, \mathrm{Ca}^{2+}, \mathrm{K}^{+}, \mathrm{Fe}^{2+}$ and $\mathrm{NO}_{3}{ }^{-}$deficient cultures showed nonsignificant increment except with $\mathrm{PO}_{4}{ }^{2-}$ deficient nutrient solution which showed nonsignificant reduction of total phenolic compounds contents. The results (Fig 5.) also showed that the only significant increment ( 2.8 folds) in total phenolic compounds content at $72 \mathrm{~h}$ cultivation time was 
Table 1. Management of particular mineral deficiency and the replacement with other salt with the final concentration for each one as describe in the materials and methods.

\begin{tabular}{lll}
\hline Deficient nutrient & Replacement & Purpose of replacement \\
\hline Complete medium & All minerals are & Presents \\
$\mathrm{Mg} / \mathrm{MgSO}{ }_{4} \cdot 7 \mathrm{H}_{2} \mathrm{O}$ & $\mathrm{NaSO}_{4}$ & Maintain the supply of sulfur \\
$\mathrm{Ca} / \mathrm{Ca}\left(\mathrm{NO}_{3}\right)_{2} \cdot 4 \mathrm{H}_{2} \mathrm{O}$ & $\mathrm{NaNO}_{3}$ & Maintain the supply of nitrogen \\
$\mathrm{Fe} / \mathrm{Fe}-\mathrm{Na}_{2} \mathrm{EDTA}$ & ------ & ------ \\
$\mathrm{P} / \mathrm{KH}_{2} \mathrm{PO}_{4}$ & $\mathrm{KCl}$ & Maintain the supply of potassium \\
$\mathrm{K} / \mathrm{KH}_{2} \mathrm{PO}_{4}$ & $\mathrm{NaNO}_{3}$ & Maintain the osmoticum \\
$\mathrm{N} / \mathrm{KNO}_{3}$ and $\mathrm{Ca}\left(\mathrm{NO}_{3}\right)_{2} \cdot 4 \mathrm{H}_{2} \mathrm{O}$ & $\mathrm{KCl}_{3}$ and $\mathrm{CaCl}_{2}$ & Maintain the supply of potassium and calcium \\
$\mathrm{S} / \mathrm{MgSO}_{4} \cdot 7 \mathrm{H}_{2} \mathrm{O}$ & $\mathrm{MgCl}_{2}$ & Maintain the supply of magnesium \\
\hline
\end{tabular}

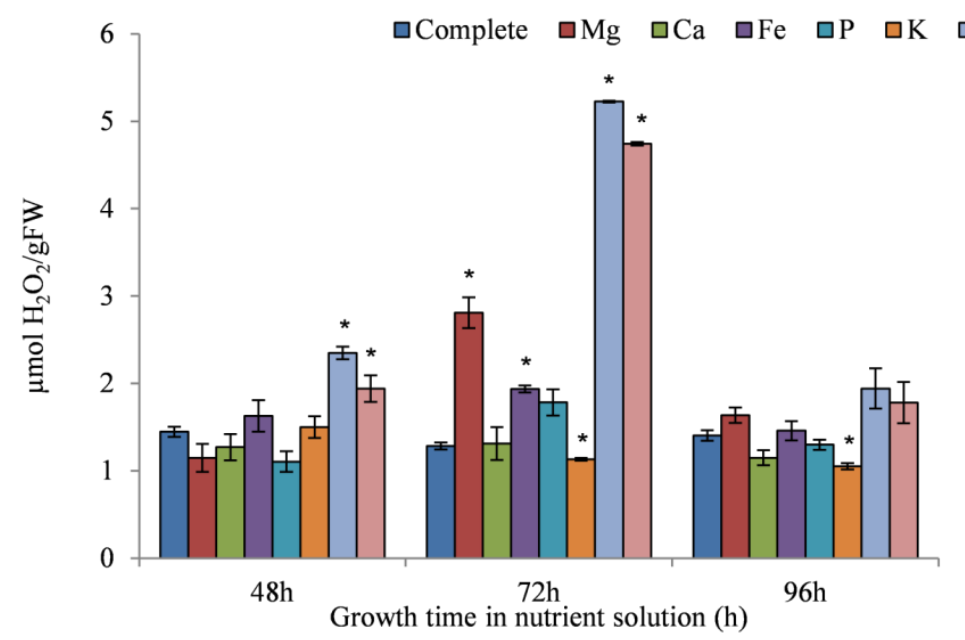

Fig 1. Hydrogen peroxide accumulation level in L. esculentum Mill. leaves in response to specific mineral deficiencies in comparison to complete nutrient solution grown plants at time dependent exposure $(* P \leq 0.05)$.

recorded in the tomato leaves of the plants that grown in $\mathrm{SO}_{4}{ }^{2-}$ specific depleted nutreint solution. However, subsequent depletion in total phenolic compounds content in test cultures at $96 \mathrm{~h}$ was observed.

\section{Lipid peroxidation level}

Figure 6. shows that lipid peroxidation levels were significantly increased and reached 5.4, 8.3, 29, 12 and 9 folds in tomato leaves after $48 \mathrm{~h}$ cultivation of tomato plants in $\mathrm{Mg}^{2+}, \mathrm{Ca}^{2+}, \mathrm{Fe}^{2+}, \mathrm{PO}_{4}{ }^{2-}$ and $\mathrm{K}^{+}$specific depleted nutreint solutions. On the other hand, the icrement in lipid peroxidation levels were nonsignificant in the case of $\mathrm{NO}_{3}{ }^{-}$ and $\mathrm{SO}_{4}{ }^{2-}$ dificient cultures. At $72 \mathrm{~h}$ cultivation, the analysis results showed that lipid peroxidation levels were further increased in tomato leaves of $\mathrm{Ca}^{2+}, \mathrm{PO}_{4}{ }^{2}$ and $\mathrm{K}^{+}$deficient cultures. Meanwhile, in the other mineral deficient cultures slight to high reduction in lipid peroxidation levels were observed. After 96h cultivation, lipid peroxidation levels were reached 2.6, 3.6 and 4.1 folds increment in tomato leaves of $\mathrm{Fe}^{2+}, \mathrm{PO}_{4}{ }^{2-}$ and $\mathrm{K}^{+}$specific depleted nutreint solution compared to the plants grown in complete nutrient solution.

\section{Discussion}

Metabolomics currently is a significant tool used to study plant acclimation to abiotic stress. Metabolome analysis showed that plant responses to abiotic stresses are dynamic and complex; they are both elastic and plastic (Cramer et al., 2011). However, wide ranges of primary and secondary metabolites are involved in the stress tolerance (Arbona et al.,
2013; Ramalingam et al., 2015; Rodziewicz et al., 2014). Under different treatments, anthocyanin accumulation is considered as a positive response to oxidative stress (Diaz et al., 2006; Hughes et al., 2010; Misyura et al., 2012). In addition, the accumulation of carotenoids is regarded to suppress the oxidation (Cao et al., 2015). Phenolic compounds may act as radical scavengers for enhancement of tolerance to oxidative stress (Kondo \& Kawashima, 2000; Michalak, 2006).

It was reported that high sugar accumulation in leaves as consequences of $\mathrm{Mg}^{2+}$ deficiency has a negative effects on transcription of photosynthesis genes in particular repress Cab2 expression. In addition, it might affect photosynthetic activity by reducing chlorophyll pigments concentration (Hermans \& Verbruggen, 2005; Liu et al., 2008). In both effect, might be depend on period of exposure beside the severity of $\mathrm{Mg}^{2+}$ limitation (Fig. 2). However, the effect was clearly after $24 \mathrm{~h}$ and $96 \mathrm{~h}, \mathrm{Mg}^{2+}$ remobilization can only prevent a drastic drop in leaves $\mathrm{Mg}^{2+}$ concentrations for a limited period following $\mathrm{Mg}^{2+}$-withdrawal as acclimation response (Fig. 2B). The increment in carotenoids/ chlorophylls ratio in $\mathrm{Mg}$-deficient plants at $72 \mathrm{~h}$ which was reached over 5folds may be an adaptive response to the elevation of $\mathrm{H}_{2} \mathrm{O}_{2}$ generation (Fig.1), to detoxify ROS. The reduction of total phenolic compounds in $\mathrm{Mg}$-deficient plants at $48 \mathrm{~h}$ might be involved directly to scavenge ROS, oxidized by peroxidase and to inhibit lipid peroxidation (Fig. 6) by trapping the lipid alkoxyl radical. Reduction of phenolic compounds strictly prevents diffusion of free radicals and restricts peroxidative reactions such as membrane damage and ions leakage (Kondo \& Kawashima, 2000; Michalak, 2006; Sharma et al., 2012). 

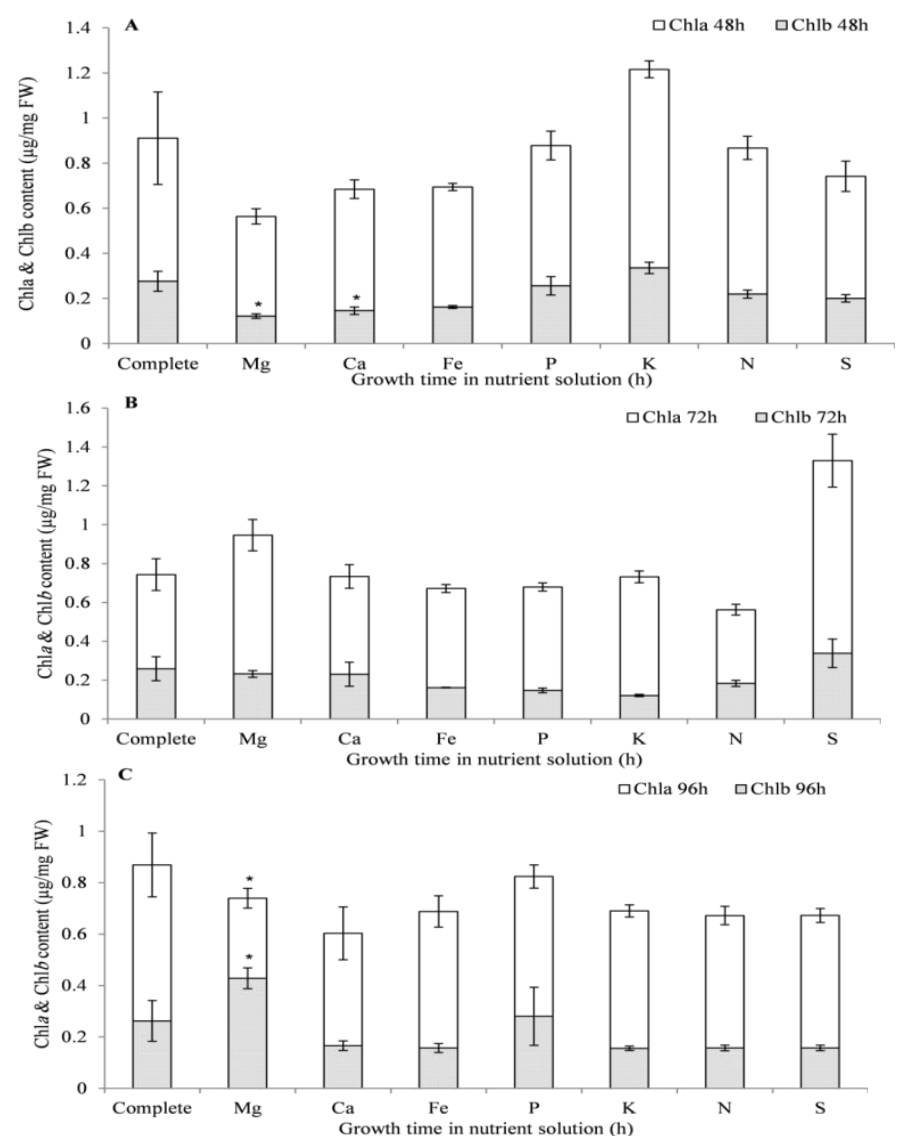

Fig 2. Chlorophyll $a$ and $b$ contents in L. esculentum Mill. leaves in response to specific mineral deficiencies in comparison to complete nutrients solution grown plants at time dependent exposure (A) 48h, (B) 72h and (C) $96 \mathrm{~h}\left({ }^{*} P \leq 0.05\right)$.

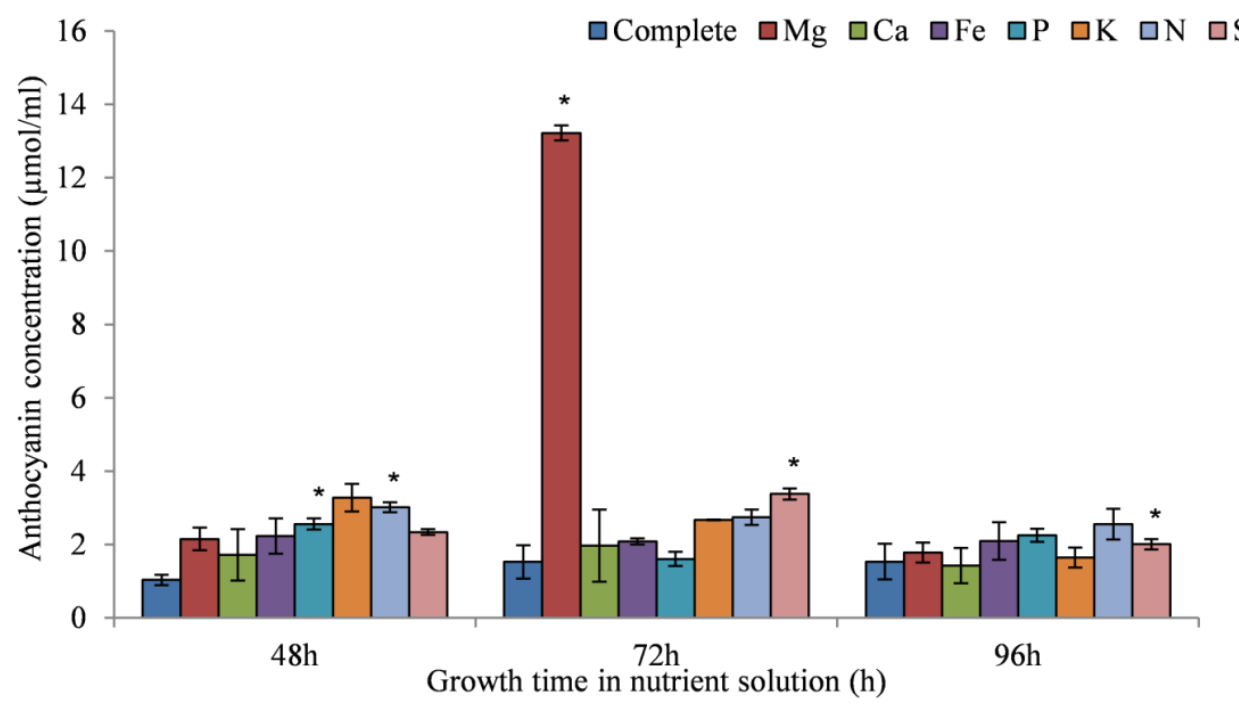

Fig 3. Anthocyanin's accumulation level in L. esculentum Mill. leaves in response to specific mineral deficiencies in comparison to complete grown plants at time dependent exposure $(* P \leq 0.05)$. 


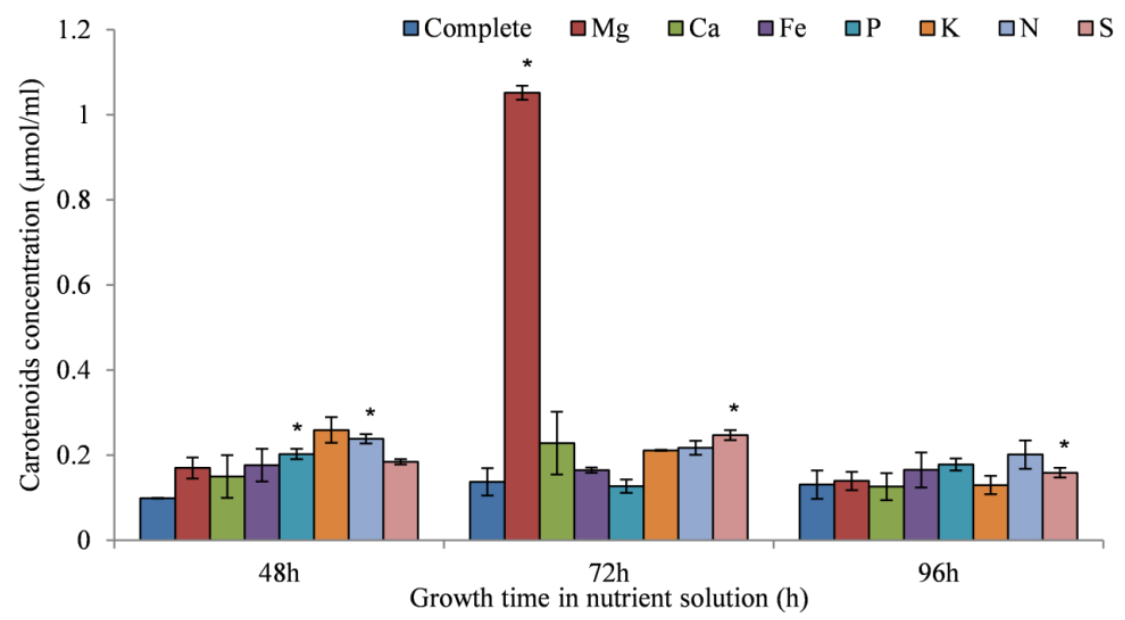

Fig 4. Carotenoids accumulation level in L. esculentum Mill. leaves in response to specific mineral deficiencies in comparison to complete grown plants at time dependent exposure $(* P \leq 0.05)$.

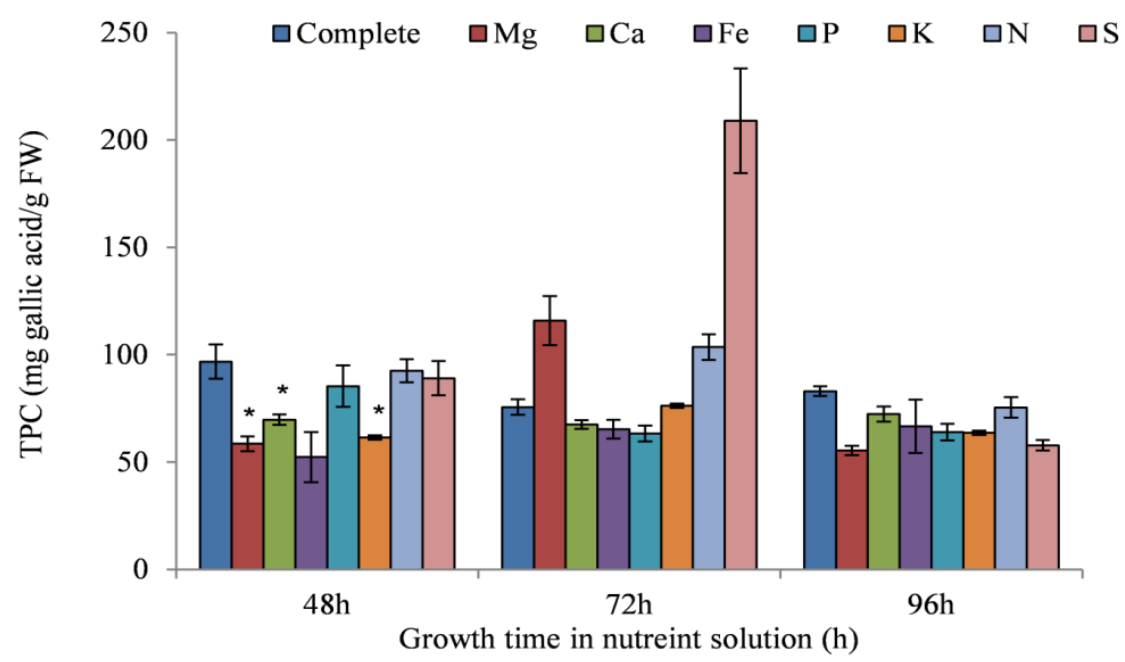

Fig 5. Total phenolic compounds (TPC) accumulation level in L. esculentum Mill. leaves in response to specific mineral deficiencies in comparison to complete grown plants at time dependent exposure $(* P \leq 0.05)$.

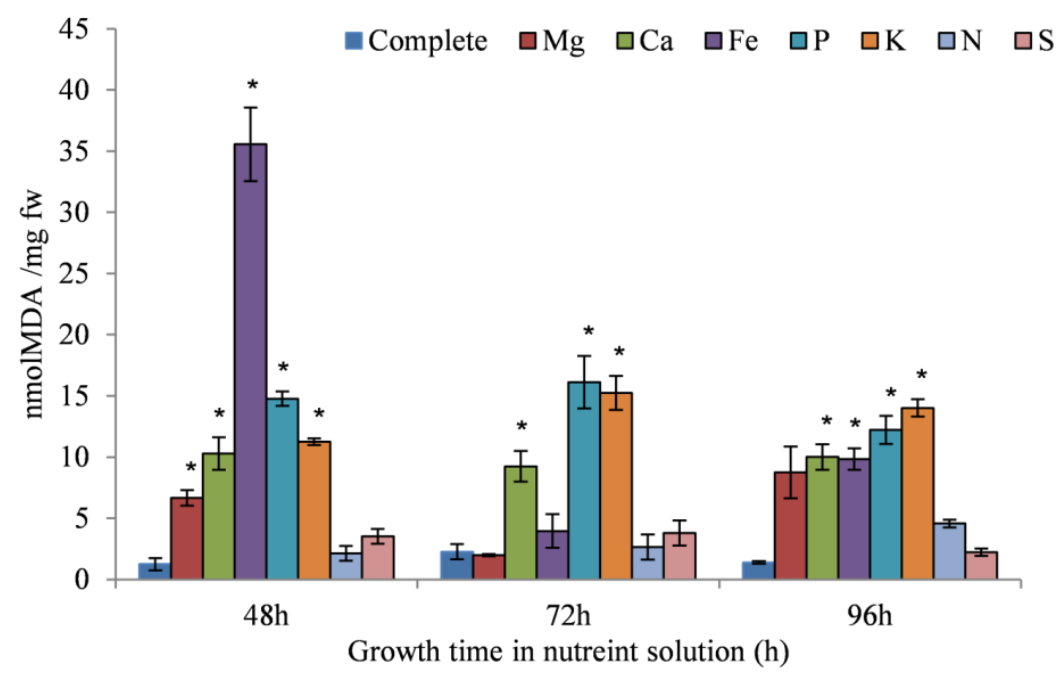

Fig 6. Lipid peroxidation level (MDA content) in L. esculentum Mill. leaves in response to specific mineral deficiencies in comparison to complete grown plants at time dependent exposure $(* P \leq 0.05)$. 
The symptoms of $\mathrm{Ca}^{2+}$ deficiency in plants were early discussed (Simon, 1978). Oxidative degradation seems to proceed at elevated rates of photosynthesis of $\mathrm{Ca}$-deficient tomato leaves and resulted in an increased malondialdehyde content in the plant tissue (Fig.7). Therefore, oxidation-prone chlorophyll in particular $\mathrm{Chl} b$ which was significantly reduced at $48 \mathrm{~h}$. This oxidation was resulting in formation of ${ }^{1} \mathrm{O}_{2}$ and other oxygen species. In consequence, the interaction between ${ }^{1} \mathrm{O}_{2}$ and membrane lipids which probably generating free radicals and decomposing membrane lipids in a chain reaction (Schmitz-Eiberger et al., 2002).

Castañeda and Pérez (1996) reported the role of $\mathrm{Ca}^{2+}$ in the synthesis of phenols. This role was not directly caused by $\mathrm{Ca}^{2+}$ ions (Ruiz et al., 2003), since $\mathrm{Ca}^{2+}$ is involved in many signal transduction pathways in plants for defense against various stresses (Tuteja \& Mahajan, 2007). Where high levels of $\mathrm{Ca}^{2+}$ ions promoted more oxidation than synthesis of phenolic compounds (Ruiz et al., 2003) as in Fig. 5 after 48h of Ca-deficient tomato leaves, which might be through the $\mathrm{Ca}^{2+}$ ions redistribution to tomato leaves especially via apoplastically to cope his role in signal transduction pathways (Gilliham et al., 2011; Tuteja \& Mahajan, 2007).

The response of $\mathrm{Fe}^{2+}$ deficient plant leaves was previously reported by Ranieri et al., (2001) through the determination of chlorophyll, carotenoids and $\mathrm{H}_{2} \mathrm{O}_{2}$ content. In $\mathrm{Fe}^{2+}$ deficient tomato leaves, the $\mathrm{H}_{2} \mathrm{O}_{2}$ content underwent increase following the iron deficiency with significant content after $72 \mathrm{~h}$ then reduced to the control level after $96 \mathrm{~h}$. The increment of $\mathrm{H}_{2} \mathrm{O}_{2}$ content suggests that $\mathrm{Fe}^{2+}$ deficiency may induce both a decreased capacity to $\mathrm{H}_{2} \mathrm{O}_{2}$ scavenging and/or an active production of $\mathrm{H}_{2} \mathrm{O}_{2}$ with a consequent rise of oxidative stress (Ranieri et al., 2001). The triggering of Fenton reaction which may explain the oxidative stress which resulted in an increased malondialdehyde content in the $\mathrm{Fe}^{2+}$ deficient plant tissues significantly after $48 \mathrm{~h}$ and $96 \mathrm{~h}$ of iron starvation (Fig.5). However, it was reported that iron deficiency differently affects peroxidase isoforms (Ranieri et al., 2001). $\mathrm{PO}_{4}{ }^{2-}$ deficient tomato leaves showed significant accumulation of anthocyanins and carotenoids contents after $48 \mathrm{~h}$ of phosphorus starvation which act as indicator of Pdeficiency stress (Awad et al., 1990; Raese, 2002; Steyn et al., 2002). This accumulation may be to increased tolerance to Pdeficiency (Gaume et al., 2001). It was reported that leaves lipid peroxidation level was increased when the $\mathrm{PO}_{4}{ }^{2^{-}}$was deficient (Chen et al., 2015) as also this study was recorded (Fig. 6). This elevation in lipid peroxidation was explained by $\mathrm{PO}_{4}{ }^{-2}$ deficiency induced the production of $\mathrm{O}_{2}^{-}$which can produce more toxic ROS, including the hydroxyl radical $\left(\mathrm{OH}^{*}\right)$ and perhydroxyl radical $\left(\mathrm{HO}_{2}{ }^{\circ}\right)$ that can initiate lipid peroxidation (Chen et al., 2015).

Potassium is essential for many physiological processes. Hence, the plants sensitivity to K-deficient was depend on the period of exposure and severity of deficiency. $\mathrm{K}^{+}$deprivation was accompanied by increases in ROS accumulation; $\mathrm{H}_{2} \mathrm{O}_{2}$ production (Shin \& Schachtman, 2004). Cakmak (1994) has been reported that K-deficient plants showed increase in peroxidases activity (ascorbate peroxidase and guaiacol peroxidase) that detoxify and utilize $\mathrm{H}_{2} \mathrm{O}_{2}$. While Liu et al., (2013) indicated that $\mathrm{K}^{+}$deficiency protects plant due to recognizable enhancement of antioxidant enzyme activities. Thereby, the significant reduction of $\mathrm{H}_{2} \mathrm{O}_{2}$ content after $72 \mathrm{~h}$ and $96 \mathrm{~h}$ in this study may as result of the increase in peroxidases activity. In contrast, K-deficient plants lipid peroxidation level was significant increased among all periods of exposure might be caused through an increase in $\mathrm{NADPH}$ dependent $\mathrm{O}_{2}{ }^{--}$generation as detected before (Cakmak, 2005). The impact of $\mathrm{K}^{+}$deprivation on chlorophyll contents was not significant effective. However, the progress in contents changes was met with those results of Cakmak (1994) that explained by ROS accumulation causing chlorophyll destruction. The biochemical responses of tomato growing in $\mathrm{K}^{+}$deprivation nutrient solution at the level of anthocyanins accumulation suggesting that $\mathrm{K}^{+}$ starvation disturbed carbon storage and transport (BattieLaclau et al., 2014) and carotenoids content was not significant change and met with results of Breś et al., (2016). The reduction in total phenolic compounds accumulation caused by $\mathrm{K}^{+}$deprivation at all the period of exposure suggesting a strong trade-off in nutrients channeled toward the production of total phenolics for their antioxidant potential (Haukioja et al., 1998; Mudau et al., 2007; Venkatesan \& Ganapathy, 2004). Deficiency of $\mathrm{NO}_{3}{ }^{-}$caused markedly increasing of hydrogen peroxide in tomato leaves (Tewari et al., 2007) which was significant increase after $48 \mathrm{~h}$ and $72 \mathrm{~h}$. This increasing still higher than that grown in complete nutrient solution after $96 \mathrm{~h}$ which may as increasing in activity of antioxidant enzymes such as superoxide dismutase, ascorbate peroxidase and glutathione reductase (Tewari et al., 2007). In the same time, this accumulation was in parallel with lipid peroxidation increasing (Tewari et al., 2007). The reduction of Chl contents caused by $\mathrm{NO}_{3}{ }^{-}$deprivation was related to chlorophyll breakdown (Diaz et al., 2006; Feild et al., 2001). The protective role for anthocyanins appeared by increasing the level significantly after $48 \mathrm{~h}$ and still higher than that grown in complete nutrient solution after $72 \mathrm{~h}$ and $96 \mathrm{~h}$ as a stress response (Chalker-Scott $\&$ Scott 2004; Diaz et al., 2006). It has been found that total phenolic compounds contents was increased to $\mathrm{NO}_{3}{ }^{-}$deprivation in tomato leaves (Løvdal et al., 2010) in particular levels of flavonoids and caffeoyl derivatives with pronounced increased levels of anthocyanin. These responses for $\mathrm{NO}_{3}{ }^{-}$deprivation were mediated by enhancement of expression of related genes at least partly be mediated through ANT1 and SIJAF13 (Løvdal et al., 2010). However, the $\mathrm{NO}_{3}{ }^{-}$deprivation effect on accumulation of phenolic compounds contents was restricted to the period of exposure (8 days as reported by Løvdal et al., 2010) which might explain the slight change in total phenolic compounds contents in this study. The present study shows that sulfur stress markedly increase in $\mathrm{H}_{2} \mathrm{O}_{2}$ concentration in tomato leaves which in consonance with reports of Chandra and Pandey (2014) and Tewari et al., (2004). Impose of $\mathrm{SO}_{4}{ }^{2}$ deprivation was in parallel with that of $\mathrm{NO}_{3}$ deprivation on tomato leaves. This suggest that $\mathrm{H}_{2} \mathrm{O}_{2}$ may be considered as a potential signaling molecule which play dual roles by induced antioxidative systems, resulting in mitigated oxidative damage (rising in MDA to nonsignificant levels). In the same time, elevate allocation of $\mathrm{NO}_{3}{ }^{-}$and $\mathrm{SO}_{4}{ }^{2-}$ to leaf resulting in enhanced $\mathrm{NO}_{3}{ }^{-}$and $\mathrm{SO}_{4}{ }^{2-}$ assimilation (Khan et al., 2016). Reduced chlorophyll contents were observed under sulfur deficiency (Ferreira \& Teixeira, 1992; Lunde et al., 2008). Chlorophyll contents after $72 \mathrm{~h}$ of exposure to $\mathrm{SO}_{4}{ }^{2-}$ deprivation showed opposite result to that of $48 \mathrm{~h}$ and 96h, this may be explained by sulfur remobilization to cope the $\mathrm{SO}_{4}{ }^{2^{-}}$deprivation (Khan et al., 2016). Where with continuous deprivation, sulfur transporters will be target of the modification and finally the $\mathrm{SO}_{4}{ }^{2-}$ deprivation symptoms as chlorosis are clearly appeared (Hawkesford, 2000).

A significant increase in anthocyanins content and the accumulation of $\mathrm{H}_{2} \mathrm{O}_{2}$ indicated that $\mathrm{SO}_{4}{ }^{2-}$ deprivation also provokes an oxidative stress in tomato leaves (D'Hooghe et al., 2013).

The $\mathrm{SO}_{4}{ }^{2-}$ deprivation grown plants rising carotenoids contents may be an acclimate response to the increased ROS 
generation, as carotenoids are known to detoxify ROS (PérezGálvez \& Mínguez-Mosquera, 2002). Among key biological functions of carotenoid is sensing and signaling the oxidative stress condition through nonenzymatic oxidation by ROS (Havaux, 2014; Ramel et al., 2012).

The study suggests that, the biosynthesis of these compounds is tightly regulated by environmental conditions such as nutrient availability. The low chlorophyll of mineral deficient leaves was specific mineral dependent then on the severity of the deficiency. The later one was nonspecific for mineral which deficient. The level of $\mathrm{H}_{2} \mathrm{O}_{2}$ was specific mineral dependent and on the severity of the deficiency as appeared in response to $\mathrm{NO}_{3}{ }^{-}$and $\mathrm{SO}_{4}{ }^{-}$deficient leaves which was early after $48 \mathrm{~h}$ and $72 \mathrm{~h}$ and in K-deficient leaves which was after $72 \mathrm{~h}$ and $96 \mathrm{~h}$.

Anthocyanin accumulation in response to nutrient availability was demonstrated by screen of anthocyanin content change with time dependent manner which indicated it strongly influenced by early deprivation of $\mathrm{K}^{+}, \mathrm{PO}_{4}{ }^{2^{-}}$and $\mathrm{NO}_{3}{ }^{-}$and then longer with $\mathrm{Mg}^{2+}$ and $\mathrm{SO}_{4}{ }^{-2}$.

\section{Materials and Methods}

\section{Plant material and growth conditions}

Tomato (Lycopersicon esculentum Mill.) seeds (BURPEE TOMATO, Super Beefsteak) placed in $9 \mathrm{~cm}$ petri dishes containing two layers of filter papers moistened with $6 \mathrm{ml}$ of sterile distilled water and incubated at $25^{\circ} \mathrm{C}$ in dark. Seedling transferred to grown for two weeks on soil mixture of peatmoss, perlite and vermiculite in prepared in the ratio of $2: 1: 1$, respectively. The seedlings were incubated under controlled conditions of $14 \mathrm{~h}$ light with $\sim 80 \mu \mathrm{mol}$ photon $\mathrm{m}^{-2}$ $\mathrm{s}^{-1}$, and $21{ }^{\circ} \mathrm{C} / 10 \mathrm{~h}$ dark and $20{ }^{\circ} \mathrm{C}, \sim 55 \%$ relative humidity).

Fourteen days old plantlets were transplanted to $100 \mathrm{ml}$ jars containing aerated nutrient solution having the chemical composition of: $10 \mathrm{mM} \mathrm{KNO} 3,10 \mathrm{mM} \mathrm{Ca}\left(\mathrm{NO}_{3}\right)_{2} \cdot 4 \mathrm{H}_{2} \mathrm{O}, 5$ $\mathrm{mM} \mathrm{MgSO}_{4} 7 \mathrm{H}_{2} \mathrm{O}, 2.5 \mathrm{mM} \mathrm{KH} \mathrm{PO}_{4}, 0.05 \mathrm{mM} \mathrm{KCl}, 0.05$ mM Fe-Na 2 EDTA, $5.0 \mathrm{mM} \mathrm{MnSO}{ }_{4}, 0.5 \mathrm{mM} \mathrm{CuSO}_{4} .5 \mathrm{H}_{2} \mathrm{O}$, $2 \mu \mathrm{M} \quad \mathrm{ZnSO}_{4} 7 \mathrm{H}_{2} \mathrm{O}, \quad 0.115 \quad \mathrm{mM} \quad \mathrm{H}_{3} \mathrm{BO}_{3}, \quad 0.1 \quad \mathrm{mM}$ $\mathrm{H}_{2} \mathrm{MoO}_{4} 2 \mathrm{H}_{2} \mathrm{O}$. The $\mathrm{pH}$ of the nutrient solution was maintained at $6.5 \pm 0.2$. Deficiency of a particular mineral nutrient was created and the replacement with equivalent moles as shown in Table 1 .

Samples of tomato leaves collected at different time points directly in liquid nitrogen and stored at $-80^{\circ} \mathrm{C}$ until the time of analysis.

\section{Measurement of $\mathrm{H}_{2} \mathrm{O}_{2}$}

The leaf hydrogen peroxide content of treated and control samples were assayed as described by Christou et al. (2013). Frozen leaf material $(\sim 0.1 \mathrm{~g})$ was homogenized on ice with $0.1 \%(\mathrm{w} / \mathrm{v})$ trichloroacetic acid (TCA). The homogenate was then centrifuged at $15,000 \mathrm{~g}$ for $15 \mathrm{~min}$. at $4{ }^{\circ} \mathrm{C}$. The supernatant was transferred to a new tube and $0.5 \mathrm{ml}$ of the supernatant was added to $0.5 \mathrm{ml}$ of $10 \mathrm{mM}$ potassium phosphate buffer ( $\mathrm{pH} \mathrm{7.0)}$ and $1 \mathrm{ml}$ of $1 \mathrm{M} \mathrm{KI}$ and mixed gently. The absorbance of the assay mixture was read at 390 $\mathrm{nm}$ and the content of $\mathrm{H}_{2} \mathrm{O}_{2}$ was calculated based on a standard curve of known concentrations of $\mathrm{H}_{2} \mathrm{O}_{2}$.

\section{Quantification \\ of chlorophylls, \\ anthocyanins \\ and Carotenoids}

For chlorophylls measurement, extraction and quantification were performed according to Porra (2002). In briefly, $20 \mathrm{mg}$ of the leaf samples were ground in $1 \mathrm{ml}$ cold $80 \%$ acetone followed by $1 \mathrm{~h}$ darkness incubation then centrifugation at $13000 \mathrm{rpm}$ at $4{ }^{\circ} \mathrm{C}$ for $10 \mathrm{~min}$, and the supernatant was read on 646.6 and $663.6 \mathrm{~nm}$. For anthocyanins and carotenoids quantification the method of Sims and Gamon (2002) was used. The procedure in principle is similar to the procedure of chlorophyll measurements except in the extraction step were extraction of anthocyanins and carotenoids performed in methanol/HCl/water (90:1:1, vol:vol:vol) mixture.

\section{Determination of total phenolic content}

Total phenolic compounds content were determined using the Folin-Ciocalteu reagent (Singleton and Rossi, 1965) and as described by $\mathrm{Lu}$ et al., (2011). In brief, $100 \mu \mathrm{l}$ of $70 \%$ methanolic leaves extract was reacted with $750 \mu 1$ of the diluted Folin-Ciocalteu reagent for $10 \mathrm{~min}$ at room temperature. Then, $750 \mu \mathrm{l}$ of $2 \%$ sodium carbonate was added. The mixture was allowed to stand in the dark (ca. 20 ${ }^{\circ} \mathrm{C}$ ) for $45 \mathrm{~min}$ before measuring the absorbance at $765 \mathrm{~nm}$ against a blank, containing deionized water instead of sample extract. TPC values were determined from a standard curve prepared of gallic acid. Results are expressed as mg of gallic acid equivalents/g fresh weight (mg GAE/g FW).

\section{Lipid peroxidation assay}

Leaf tissue (50 mg) was homogenized in $1 \mathrm{~mL}$ of $80 \%$ (v/v) ethanol on ice. The homogenate was centrifuged at $16,000 \mathrm{~g}$ for $20 \mathrm{~min}$ at $4{ }^{\circ} \mathrm{C}$. The supernatant $(0.5 \mathrm{~mL})$ was mixed with $0.5 \mathrm{~mL}$ of $20 \%$ (w/v) trichloroacetic acid containing $0.65 \%$ (w/v) thiobarbituric acid, followed with direct incubation at $95^{\circ} \mathrm{C}$ for $30 \mathrm{~min}$. then immediately cooled on ice. The absorbance of the supernatant was measured, after centrifugation at $10,000 \mathrm{~g}$ for $10 \mathrm{~min}$., at $532 \mathrm{~nm}$, subtracting the value for nonspecific absorption at $600 \mathrm{~nm}$. The level of lipid peroxidation was measured through calculating malondialdehyde (MDA) concentration from the extinction coefficient $155 \mathrm{mM}^{-1} \mathrm{~cm}^{-1}$ (Hodges et al., 1999).

\section{Statistical analysis}

For all experiment, samples of the plant leaves were analyzed and all the assays were carried out in triplicate for each of three independent biological samples. The results were expressed as mean \pm SD. The comparison between two samples was performed by student's $t$-test and the $P$ values of $\leq 0.05$ were considered as significant.

\section{Conclusion}

These metabolome readjustment of plant cells internal environment reflects plant plasticity for acclimation to different abiotic stress factors, in particular mineral deficiencies. However, extended study to include other possible factors such as the antioxidant enzymes (in particular total ascorbate peroxidases, polyphenol oxidase, and phenylalanine ammonia lyase) to understand the process of Lycopersicon esculentum Mill. leaves acclimation in response to mineral deficiencies is required. 


\section{Acknowledgements}

Author is thankful to the Deanship of Scientific Research in Mu'tah University-Jordan for the financial support of this project with the reference number (NO.120/14/320). The author is also grateful to Mrs. Manar Alotosh and Mrs. Muradi bani Yunis for conducting the experiments.

\section{References}

Arbona V, Manzi M, Ollas CD, Gómez-Cadenas A (2013) Metabolomics as a tool to investigate abiotic stress tolerance in plants. Int J Mol Sci. 14(3):4885-4911.

Awad AS, Edwards DG, Campbell LC (1990) Phosphorus enhancement of salt tolerance of tomato. Crop Sci. 30(1):123-128.

Battie-Laclau P, Laclau JP, Beri C, Mietton L, Muniz MRA, Arenque BC, Piccolo MC, Jordan-Meille L, Bouillet J-P, Nouvellon Y (2014) Photosynthetic and anatomical responses of Eucalyptus grandis leaves to potassium and sodium supply in a field experiment. Plant Cell Environ. 37(1):70-81.

Breś W, Bandurska H, Kupska A, Niedziela J, Frąszczak B (2016) Responses of pelargonium (Pelargonium $\times$ hortorum LH Bailey) to long-term salinity stress induced by treatment with different $\mathrm{NaCl}$ doses. Acta Physiol Plant. 38(1):1-11.

Cakmak I (1994) Activity of ascorbate-dependent $\mathrm{H}_{2} \mathrm{O}_{2}$ scavenging enzymes and leaf chlorosis are enhanced in magnesium-and potassium-deficient leaves, but not in phosphorus-deficient leaves. J Exp Bot. 45(9):1259-1266.

Cakmak I (2005) The role of potassium in alleviating detrimental effects of abiotic stresses in plants. J Plant Nutr Soil Sc. 168(4):521-530.

Cao H, Wang J, Dong X, Han Y, Ma Q, Ding Y, Zhao F, Zhang J, Chen H, Xu Q, Xu J, Deng X (2015) Carotenoid accumulation affects redox status, starch metabolism, and flavonoid/anthocyanin accumulation in citrus. BMC Plant Biol. 15(1):27.

Castañeda P, Pérez L. M (1996) Calcium ions promote the response of Citrus limon against fungal elicitors or wounding. Phytochemistry. 42(3):595-598.

Chalker-Scott L, Scott JD (2004) Elevated ultraviolet-B radiation induces cross-protection to cold in leaves of Rhododendron under field conditions. Photochem Photobiol. 79(2):199-204.

Chandra N, Pandey N (2014) Antioxidant status of Vigna mungo L. in response to sulfur nutrition. Chinese Journal of Biology. 2014:724523, 9 pages.

Chen S, Zhao H, Ding G, Xu F (2015) Genotypic differences in antioxidant response to phosphorus deficiency in Brassica napus. Plant Soil. 391(1-2):19-32.

Chon SU, Boo HO, Heo BG, Gorinstein S (2012) Anthocyanin content and the activities of polyphenol oxidase, peroxidase and phenylalanine ammonia-lyase in lettuce cultivars. Int J Food Sci Nutr. 63(1):45-48.

Christou A, Manganaris GA, Papadopoulos I, Fotopoulos V (2013) Hydrogen sulfide induces systemic tolerance to salinity and non-ionic osmotic stress in strawberry plants through modification of reactive species biosynthesis and transcriptional regulation of multiple defence pathways. J Exp Bot. 64(7):1953-1966.

Cramer GR, Urano K, Delrot S, Pezzotti M, Shinozaki K (2011) Effects of abiotic stress on plants: a systems biology perspective. BMC Plant Biol. 11(1):163.

D’Hooghe P, Escamez S, Trouverie J, Avice JC (2013) Sulphur limitation provokes physiological and leaf proteome changes in oilseed rape that lead to perturbation of sulphur, carbon and oxidative metabolisms. BMC Plant Biol. 13(1):1.

Diaz C, Saliba-Colombani V, Loudet O, Belluomo P, Moreau L, Daniel-Vedele F, Morot-Gaudry J-F, MasclauxDaubresse C (2006) Leaf yellowing and anthocyanin accumulation are two genetically independent strategies in response to nitrogen limitation in Arabidopsis thaliana. Plant Cell Physiol. 47(1):74-83.

Do CB, Cormier F (1991) Accumulation of peonidin 3glucoside enhanced by osmotic stress in grape (Vitis vinifera L.) cell suspension. Plant Cell Tiss Organ Cult. 24(1):49-54.

Feild TS, Lee DW, Holbrook NM (2001) Why leaves turn red in autumn. The role of anthocyanins in senescing leaves of red-osier dogwood. Plant Physiol. 127(2):566-574.

Ferreira RM, Teixeira AR (1992) Sulfur starvation in Lemna leads to degradation of ribulose-bisphosphate carboxylase without plant death. J Biol Chem. 267(11):7253-7257.

Gao Y, Guo YK, Lin SH, Fang YY, Bai JG (2010) Hydrogen peroxide pretreatment alters the activity of antioxidant enzymes and protects chloroplast ultrastructure in heatstressed cucumber leaves. Sci Hortic -Amsterdam. 126(1):20-26.

Garcia-Salas P, Morales-Soto A, Segura-Carretero A, Fernández-Gutiérrez A (2010) Phenolic-compoundextraction systems for fruit and vegetable samples. Molecules. 15(12): 8813-8826.

Gaume A, Mächler F, De León C, Narro L, Frossard E (2001) Low-P tolerance by maize (Zea mays L.) genotypes: significance of root growth, and organic acids and acid phosphatase root exudation. Plant Soil. 228(2):253-264.

Gilliham M, Dayod M, Hocking BJ, Xu B, Conn SJ, Kaiser BN, Leigh RA, Tyerman SD (2011) Calcium delivery and storage in plant leaves: exploring the link with water flow. J Exp Bot. 62(7):2233-2250.

Havaux M (2014) Carotenoid oxidation products as stress signals in plants. Plant J. 79(4): 597-606.

Haukioja E, Ossipov V, Koricheva J, Honkanen T, Larsson S, Lempa K (1998) Biosynthetic origin of carbon-based secondary compounds: cause of variable responses of woody plants to fertilization?. Chemoecology. 8(3):133139.

Hawkesford MJ (2000) Plant responses to sulphur deficiency and the genetic manipulation of sulphate transporters to improve S-utilization efficiency. J Exp Bot. 51(342):131138 .

Hermans C, Verbruggen N (2005) Physiological characterization of $\mathrm{Mg}$ deficiency in Arabidopsis thaliana. J Exp Bot. 56(418):2153-2161.

Hermans C, Hammond JP, White PJ, Verbruggen N (2006) How do plants respond to nutrient shortage by biomass allocation?. Trends Plant Sci. 11(12):610-617.

Hodges DM, DeLong JM, Forney CF, Prange RK (1999) Improving the thiobarbituric acid-reactive-substances assay for estimating lipid peroxidation in plant tissues containing anthocyanin and other interfering compounds. Planta. 207(4):604-611.

Hughes NM, Reinhardt K, Field TS, Gerardi AR, Smith WK (2010) Association between winter anthocyanin production and drought stress in angiosperm evergreen species. J Exp Bot. 61:1699-1709.

Kehr J (2013) Systemic regulation of mineral homeostasis by micro RNAs. Front Plant Sci. 4:145.

Khan MIR, Khan NA, Masood A, Per TS, Asgher M (2016) Hydrogen Peroxide Alleviates Nickel-Inhibited Photosynthetic Responses through Increase in Use- 
Efficiency of Nitrogen and Sulfur, and Glutathione Production in Mustard. Front Plant Sci. 7:44.

Kobayashi Y, Akita M, Sakamoto K, Liu H, Shigeoka T, Koyano T, Kawamura M, Furuya T (1993) Large-scale production of anthocyanin by Aralia cordata cell suspension cultures. Appl Microbiol Biot. 40(2-3):215-218.

Kondo N, Kawashima M (2000) Enhancement of the tolerance to oxidative stress in cucumber (Cucumis sativus L.) seedlings by UV-B irradiation: possible involvement of phenolic compounds and antioxidative enzymes. J Plant Res. 113(3):311-317.

Liu CH, Chao YY, Kao CH (2013) Effect of potassium deficiency on antioxidant status and cadmium toxicity in rice seedlings. Bot Stud. 54(1):1-10.

Liu H, Chen X, Chen R, Song S, Sun G (2008) Effects of magnesium deficiency on growth and photosynthesis of flowering Chinese cabbage. Acta Hortic. 767:169-175.

Løvdal T, Olsen KM, Slimestad R, Verheul M, Lillo C (2010) Synergetic effects of nitrogen depletion, temperature, and light on the content of phenolic compounds and gene expression in leaves of tomato. Phytochemistry. 71(5):605-613.

Lunde C, Zygadlo A, Simonsen HT, Nielsen PL, Blennow A, Haldrup A (2008) Sulfur starvation in rice: the effect on photosynthesis, carbohydrate metabolism, and oxidative stress protective pathways. Physiol Plantarum. 134(3):508521.

Michalak A (2006) Phenolic compounds and their antioxidant activity in plants growing under heavy metal stress. Pol J Environ Stud. 15(4):523.

Misyura M, Colasanti J, Rothstein SJ (2012) Physiological and genetic analysis of Arabidopsis thaliana anthocyanin biosynthesis mutants under chronic adverse environmental conditions. J Exp Bot. 64 (1):229-240.

Mori T, Sakura M (1994) Production of anthocyanin from strawberry cell suspension cultures; effects of sugar and nitrogen. J Food Sci. 59(3):588-593.

Mudau FN, Soundy P, du Toit ES (2007) Effects of nitrogen, phosphorus, and potassium nutrition on total polyphenol content of bush tea (Athrixia phylicoides L.) leaves in shaded nursery environment. HortScience. 42(2):334-338.

Nakajima H, Sonomoto K, Sato F, Ichimura K, Yamada Y, Tanaka A (1989) Influence of carbon source on pigment production by immobilized cultured cells of Lavandula vera. J Ferment Bioeng. 68(5):330-333.

Orozco-Cárdenas ML, Narváez-Vásquez J. Ryan CA (2001) Hydrogen peroxide acts as a second messenger for the induction of defense genes in tomato plants in response to wounding, systemin, and methyl jasmonate. Plant Cell. 13(1):179-191.

Pérez-Gálvez A, Mínguez-Mosquera MI (2002) Degradation of non-esterified and esterified xanthophylls by free radicals. Biochim Biophys Acta. 1569(1):31-34.

Porra RJ (2002) The chequered history of the development and use of simultaneous equations for the accurate determination of chlorophylls $a$ and $b$. Photosynth Res.73:149-156.

Prasad TK, Anderson MD, Martin BA, Stewart CR (1994) Evidence for chilling-induced oxidative stress in maize seedlings and a regulatory role for hydrogen peroxide. Plant Cell. 6(1):65-74.

Quan LJ, Zhang B, Shi WW, Li HY (2008) Hydrogen peroxide in plants: a versatile molecule of the reactive oxygen species network. J Integr Plant Biol. 50(1):2-18.

Raese JT (2002) Phosphorus deficiency symptoms in leaves of apple and pear trees as influenced by available soil phosphorus. Commun Soil Sci Plan. 33(3-4):461-477.
Ramalingam A, Kudapa H, Pazhamala LT, Weckwerth W, Varshney RK (2015) Proteomics and Metabolomics: two emerging areas for legume improvement. Front Plant Sci. 6:1116.

Ramel F, Birtic S, Ginies C, Soubigou-Taconnat L, Triantaphylidès C, Havaux M (2012) Carotenoid oxidation products are stress signals that mediate gene responses to singlet oxygen in plants. P Natl Acad Sci USA. 109(14):5535-5540.

Ranieri A, Castagna A, Baldan B, Soldatini GF (2001) Iron deficiency differently affects peroxidase isoforms in sunflower. J Exp Bot. 52(354):25-35

Rodziewicz P, Swarcewicz B, Chmielewska K, Wojakowska A, Stobiecki M (2014) Influence of abiotic stresses on plant proteome and metabolome changes. Acta Physiol Plant. 36(1):1-19.

Ruiz JM, Rivero RM, Lopez-Cantarero I, Romero L (2003) Role of $\mathrm{Ca}^{2+}$ in the metabolism of phenolic compounds in tobacco leaves (Nicotiana tabacum L.). Plant Growth Regul. 41(2): 173-177.

Sakihama Y, Cohen MF, Grace SC, Yamasaki H (2002) Plant phenolic antioxidant and prooxidant activities: phenolicsinduced oxidative damage mediated by metals in plants. Toxicology. 177:67-80.

Schmitz-Eiberger M, Haefs R, Noga G (2002) Calcium deficiency-Influence on the antioxidative defense system in tomato plants. J Plant Physiol. 159(7):733-742.

Sharma P, Jha AB, Dubey RS, Pessarakli M (2012) Reactive oxygen species, oxidative damage, and antioxidative defense mechanism in plants under stressful conditions. Journal of Botany. 2012:217037.

Shin R, Schachtman DP (2004) Hydrogen peroxide mediates plant root cell response to nutrient deprivation. P Natl Acad Sci USA. 101(23):8827-8832.

Simon EW (1978) The symptoms of calcium deficiency in plants. New Phytol. 80(1):1-15.

Sims DA, Gamon JA (2002) Relationships between leaf pigment content and spectral reflectance across a wide range of species, leaf structures and developmental stages. Remote Sens Environ. 81(2):337-354.

Singleton VL, Rossi JA (1965) Colorimetry of total phenolics with phosphomolybdic-phosphotungstic acid reagents. Am J Enol Viticult. 16:144-158.

Steyn WJ, Wand SJE, Holcroft DM, Jacobs G (2002) Anthocyanins in vegetative tissues: a proposed unified function in photoprotection. New Phytol. 155(3):349-361.

Tewari RK, Kumar P, Sharma PN (2007) Oxidative stress and antioxidant responses in young leaves of mulberry plants grown under nitrogen, phosphorus or potassium deficiency. J Integr Plant Biol. 49(3):313-322.

Tewari RK, Kumar P, Tewari N, Srivastava S, Sharma PN (2004) Macronutrient deficiencies and differential antioxidant responses-influence on the activity and expression of superoxide dismutase in maize. Plant Sci. 166(3):687-694

Trachootham D, Lu W, Ogasawara MA, Valle NRD, Huang P (2008) Redox regulation of cell survival. Antioxid Redox Sign. 10(8):1343-1374.

Tsao R, McCallum J (2009) Chemistry of Flavonoids. In Fruit and Vegetable Phytochemicals: Chemistry, Nutritional Value and Stability; de la Rosa LA, AlvarezParrilla E, Gonzalez-Aguilar G, Eds.; Blackwell Publishing: Ames, IA, USA; Chapter 5, pp. 131-153.

Tuteja N, Mahajan S (2007) Calcium signaling network in plants: an overview. Plant Signal Behav. 2(2):79-85. 
Tuteja N, Sopory SK (2008) Chemical signaling under abiotic stress environment in plants. Plant Signal Behav. 3(8):525-536.

Venkatesan S, Ganapathy MNK (2004) Impact of nitrogen and potassium fertiliser application on quality of CTC teas. Food Chem. 84(3):325-328.

Verbruggen N, Hermans C (2013) Physiological and molecular responses to magnesium nutritional imbalance in plants. Plant Soil. 368(1-2):87-99.

Wang YH, Garvin DF, Kochian LV (2002) Rapid induction of regulatory and transporter genes in response to phosphorus, potassium, and iron deficiencies in tomato roots. Evidence for cross talk and root/rhizospheremediated signals. Plant Physiol. 130(3):1361-1370.

Wang Y, Wu WH (2010) Plant sensing and signaling in response to $\mathrm{K}^{+}$-deficiency. Mol Plant. 3(2):280-287.
Wellmann E, Hrazdina G, Grisebach H (1976) Induction of anthocyanin formation and of enzymes related to its biosynthesis by UV light in cell cultures of Haplopappus gracilis. Phytochemistry. 15(6):913-915.

Zhang W, Seki M, Furusaki S (1997) Effect of temperature and its shift on growth and anthocyanin production in suspension cultures of strawberry cells. Plant Sci. 127(2):207-214

Zhong JJ, Seki T, Kinoshita SI, Yoshida T (1991) Effect of light irradiation on anthocyanin production by suspended culture of Perilla frutescens. Biotechnol Bioeng. 38(6):653658. 